\title{
Toxicity of Granules of Bintaro Leaf Extract (Cerbera odollam Gaertn.) on Armyworm (Spodoptera litura Fab.)
}

\author{
Ahmad Habib Sholahuddin 1), Wachju Subchan ${ }^{1)}{ }^{凶}$, Jekti Prihatin 1) \\ ${ }^{1}$ Biology Education, Faculty of Teacher Training and Education, University of Jember \\ Email: wachju.fkip@unej.ac.id
}

\begin{abstract}
Grayak caterpillar is insect pests that become pests of various food crops. Grayak caterpillars cause a decrease in crop productivity and even crop failure if they are not controlled. Pest control using chemical pesticides has many adverse effects on the environment. To minimize the occurrence of environmental damage, then it is used pest control using vegetable insecticides. Bintaro Leaf (Cerbera odollam Gaertn.) is potential as a vegetable insecticide. The purpose of this study was to examine the toxicity of granule from Bintaro leaf extract (C. odollam Gaertn.) on armyworms ( . litura Fab.). This research was a laboratory experimental research using Completely Randomized Design (CRD). Serial concentrations used in this study were $0 \%$ (control), $0.5 \%, 1 \%, 1.5 \%, 2 \%$, and $2.5 \%$. The results of this study showed that the granules of Bintaro leaf extract (C. odollam Gaertn.) were effective in causing mortality of armyworms ( $S$. litura Fab.) at $1.5 \%$ concentration by $60 \%$ and included in toxic category. The value of $\mathrm{LC}_{50}-48$ hour granule from Bintaro leaf extract (C. odollam Gaertn) was $1.41 \%$.
\end{abstract}

Keywords: Spodoptera litura Fab. , Granula extract of Cerbera odollam Gaertn., Vegetable Insecticide.

\section{INTRODUCTION}

Grayak caterpillars (Spodoptera litura Fab.) are known as plant-disturbing organisms (PDOs) that often cause damage to horticultural crops, both fruits and vegetables, such as soybeans, cabbage, and mustard greens. Loss of crop production due to the attack of $S$. litura Fab. can reach $85 \%$, can even lead to crop failure, so that it damages agricultural commodities [2]. In order to control S. litura Fab., farmers generally use high-frequency chemical insecticides to control S. litura Fab. [3].

The use of chemical insecticides results in negative and detrimental effects such as the emergence of resistance symptoms, pest resurgence (a phenomenon of increased pest attacks after insecticide treatment), the killing of natural enemies, increasing residue on yields, polluting the environment, and impairing health for users [4].

Reducing the use of chemical insecticides in agricultural areas demands the availability of other safe and environmentally friendly means of control, such as by utilizing natural enemies and the use of plant-based insecticides [5]. One of plants that can be used as a vegetable insecticide is the Bintaro plant (Cerbera odollam Gaertn.). This plant is entirely toxic because it contains compounds of alkaloid groups that are repellent and antifeedant [6]. In its leaves, it contains of saponins, flavonoids and the specific content of the Bintaro plant (C. odollam Gaertn.) is Cerberin which is known to be highly toxic to insects and can inhibit pest feeding activity [7].

Bintaro leaf extract has an effect on the mortality of $S$. litura Fab., The higher the concentration, then the more the mortality rate of $S$. litura Fab. increases [8]. The concentration of $C$. odollam Gaertn leaf extract is proportional to the development of the larvae, the higher of the concentration then the development of test insects is also increasingly inhibited [9]. Rough extract of $C$. odollam Gaertn leaf. has a strong insecticidal activity against the larvae of $S$. litura Fab. with $\mathrm{LC}_{50}-48 \mathrm{hrs}$ of $0.6 \%$ against instar larvae II and $0.28 \%$ against instar larvae III and IV [10].

Some weaknesses in the utilization of extraction results are impractical in their use and are often susceptible to damage, requiring further effort to convert Bintaro leaf extract ( $C$. odollam Gaertn.) in the form 
of durable granules and do not decrease the effectiveness of biopesticides. Development of vegetable insecticide material from Bintaro leaf ( $C$. odollam Gaertn.) in the form of granule aims for longer durability, easy to carry everywhere, and relatively practical in its use.

\section{RESEARCH METHOD}

This type of research is an experimental research using Completely Randomized Design (CRD). This study used five levels of treatment and one control. The concentration of granules extract used was concentration of research that were $0.5 \%, 1 \%, 1.5 \%, 2 \%, 2.5 \%$ and $100 \mathrm{ml}$ of aquades as control. Each treatment and control use four repetitions. Each repetition contains $10 \mathrm{~S}$. litura Fab. instar III.

To determine the percentage mortality of armyworms ( $S$. litura Fab.) due to the treatment of granule of Bintaro leaf extract (C. odollam Gaertn.) it was corrected by Abbot's formula as follows [11].

Note:

$$
\mathrm{P}=\frac{p *-C}{1-C}
$$

$\mathrm{P}$ : Experimental treatment response corrected for the control response

$\mathrm{P}^{*}$ : Experimental treatment response C : Control response

Data analysis used to determine the killing power of granule from Bintaro leaf extract (C. odollam Gaertn.) to armyworms larvae (S. litura Fab.) in $\mathrm{LC}_{50}$ form was probit analysis with Minitab 14 version software from mortality data.

\section{RESULT AND DISCUSSION}

a. Homogeneity Test of Worms Weight Before Treatment of Bintaro Leaf Extract Granules (Cerbera odollam Gaertn.)

Homogeneity test results showed that the weight of worms before granulation treatment of Bintaro leaf extract $(C$. odollam Gaertn.) was not significantly different, ie seen from the significance value of 0.973 greater than 0.05 . b. Granules of Bintaro leaf extract (Cerbera odollam Gaertn.) on S. litura Fab. mortality

Mortality in this study is the number of deaths of S. litura Fab. during the study which is calculated in the form of a percentage. Spodoptera litura Fab. percent mortality rate can be seen in Figure 1.

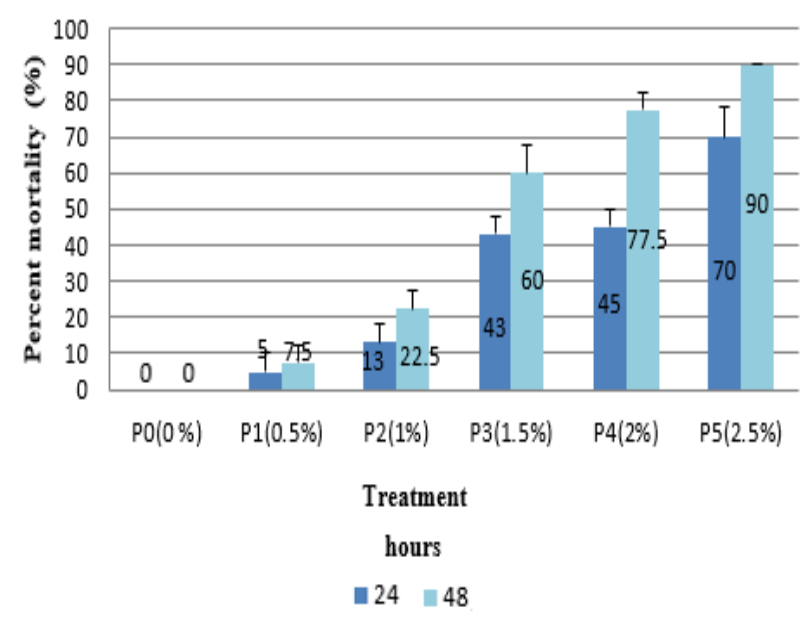

Figure 1. Histogram of percentage average of Spodoptera litura Fab. mortality on the granule treatment of bintaro leaf extract with exposed time about 24 hours and 48 hours.

From Figure 1. it can be seen that the mortality of $S$. litura Fab. with a 24-hours exposed time from the largest to the smallest consecutively occurred in P5 (2.5\%) of $70 \%$, P4 (2\%) of $45 \%$, P3 (1.5\%) of $43 \%$, P2 $(1 \%)$ by $13 \%, \mathrm{P} 1(0.5 \%)$ by $5 \%$, and P0 $(0 \%)$ by $0 \%$. It is known that the mortality of $S$. litura Fab. with 48-hours exposed time from the biggest to the smallest consecutively happened at P5 $(2.5 \%)$ equal to $90 \%$, P4 (2\%) equal to $77.5 \%, \mathrm{P} 3(1.5 \%)$ equal to $60 \%, \mathrm{P} 2(1 \%)$ by $22.5 \%, \mathrm{P} 1(0.5 \%)$ by $7.5 \%$, and $\mathrm{P} 0(0 \%)$ by $0 \%$.

c. The value of Lethal Concentration $\left(\mathrm{LC}_{50}\right)$ granule of Bintaro leaf extract (Cerbera odollam Gaertn.)

Lethal Concentration $\left(\mathrm{LC}_{50}\right)$ is expressed as a concentration of insecticide that can kill half of the animal population 
after a period of time. Based on probit analysis that has been done by using Minitab software 14 version, it can be seen that $\mathrm{LC}_{50}$ value - 48 hours of exposed time repetition in Table 1.

Table $1 . \mathrm{LC}_{50}$ value, upper limit and lower limit of granules of bintaro leaf extract with an exposed time of 48 hours

\begin{tabular}{cccc}
\hline Treatment & $\begin{array}{c}\text { LC }_{50} \\
\text { Value } \\
(\%)\end{array}$ & $\begin{array}{c}\text { The } \\
\text { lower } \\
\text { limit } \\
(\%)\end{array}$ & $\begin{array}{c}\text { The } \\
\text { upper } \\
\text { limit } \\
(\%)\end{array}$ \\
\hline $\begin{array}{c}\text { granules } \\
\text { extract of } \\
\text { bintaro leaf }\end{array}$ & 1.41 & 1.24 & 1.56 \\
\hline
\end{tabular}

From the table, it can be seen that the value of $\mathrm{LC}_{50}-48$ hours is 1.41 with the lower limit of $1.24 \%$ and the upper limit of $1.56 \%$. It means that to get the death of larvae about $50 \%$ by using the granule of Bintaro leaf extract (C. odollam Gaertn.) is not less than $1.24 \%$ and not more than $1.56 \%$.

\section{d. TLC (Thin Layer Chromatography) Granules of Bintaro Leaf Extract $(C$. odollam Gaertn.) \\ TLC (Thin Layer Chromatography)} is a test used in this study to detect a compound. The TLC test can be seen in Table 2.

Table 2. TLC granule test of Bintaro leaf extract (C. odollam Gaertn.)

\begin{tabular}{c|cccc}
\hline Bintaro & \multicolumn{4}{|c}{ Type of Test } \\
\cline { 2 - 5 } Leaf & Alkaloids & Flavonoids & Saponins & Tannins \\
\cline { 2 - 5 } Extract & + & + & + & +
\end{tabular}

Note:

+ : Available

- : Unavailable

From Table 2, it can be seen that the granules of Bintaro leaf extract (Cerbera odollam Gaertn.) contain secondary metabolite compounds namely alkaloids, flavonoids, saponins, and tannins.

\section{DISCUSSION}

Toxicity of the granules of bintaro leaf extract (Cerbera odollam Gaertn.) can be seen from its effect on the armyworms (Spodoptera litura Fab.). which are used as test insects. S. litura Fab. obtained from BALITTAS Malang. The parameters observed in this study were the number of larval mortality of $S$. litura Fab. S. litura Fab. mortality is used to determine the magnitude of $\mathrm{LC}_{50}-48$ hours.

Application of the granules of bintaro leaf extracts was done after measuring the weight of each worm. The data weight of worms obtained was tested first with homogeneity test to know that the data was not significantly different. In the test, it was obtained significance value of 0.973 which means no significantly different.

Based on the research, it was found that the use of granules of bintaro leaf extract had an effect on the $S$. litura Fab. mortality. From the data obtained, it showed that the treatment at all concentration levels found the death of $S$. litura Fab. except control $(0 \%)$ with no deaths. Figure 1 shows the amount of worms mortality at various concentrations. The addition of concentration of bintaro leaf extract causes an increase in worms mortality. [8] stated that the higher concentrations used in testing, the mortality rate of $S$. litura Fab. is more increasing.

The chemical content contained in bintaro leaves can be used as a plant-based insecticide against the mortality of Spodoptera litura Fab. [12] reported that bioactive compounds are almost always toxic at high doses. Every chemical including the active compound of the plant is essentially toxic, depending on the use, the dosage, the preparation, and the manner in which it is used. Input of secondary metabolite compounds into the body of the larvae can damage the larvae organ system and inhibit larval activity. The content of secondary metabolic compounds causes the death of larvae [13].

Granules of bintaro leaf extracts caused the mortality of Spodoptera litura Fab. increasing on every concentration increase. $0.5 \%$ concentration is capable of killing Spodoptera litura Fab. by $7.5 \%$ with 
an average mortality of 0.75 tail. A $1 \%$ concentration is capable of killing Spodoptera litura Fab. amounted to $22.5 \%$ with an average mortality of 2.25 tail. A $1.5 \%$ concentration is capable of killing Spodoptera litura Fab. of $60 \%$ with an average mortality of 6 tails. A $2 \%$ concentration is capable of killing Spodoptera litura Fab. amounted to $77.5 \%$ with an average mortality of 7.75 tail. $2.5 \%$ concentration is capable of killing Spodoptera litura Fab. of $90 \%$ with an average mortality of 9 tails. While in the control treatment $(0 \%)$, it did not experience the death of Spodoptera litura Fab.

Based on the result of probit analysis that has been done by using Minitab software 14 version it can be determined the value of $\mathrm{LC}_{50}$ from granule extract of bintaro leaf. The $\mathrm{LC}_{50}$ value of granules of bintaro leaf extract has a strong insecticidal activity effect on armyworms (Table 4.2). The $\mathrm{LC}_{50}$ is $1.41 \%$ with the lower limit of $1.24 \%$ and the upper limit of $1.56 \%$. This means that to obtain the death of larvae by $50 \%$ by using the granule of Bintaro leaf extract (C. odollam Gaertn.) is not less than $1.24 \%$ and not more than $1.56 \%$. Utami et al., Reported that bintaro leaf extract had a strong toxic effect on $S$. litura Fab. both instar two and three. If an insecticide has an $\mathrm{LC}_{50}$ value at high concentrations then the insecticidal toxicity will be low. On the contrary, the lower the $\mathrm{LC}_{50}$ value the higher the insecticidal toxicity [14]. Thus, the granules of Bintaro leaf extract $(C$. odollam Gaertn.) have high toxicity and can kill $50 \%$ of the population of armyworms (S. litura Fab). which is tested.

Spodoptera litura Fab. experienced death caused by the toxic effects possessed by granules of bintaro leaf extract that can enter into the body of larvae through two ways, namely stomach toxin and contact toxin. Stomach toxin is a type of insecticide that is eaten by insects and kills the insect in particular by destroying or absorbing the digestive system. Contact toxin is a type of insecticide that is absorbed through the body wall so that the insect has to feel in direct contact with the insecticide [15].
Based on TLC test (thin layer chromatography) on granule of bintaro leaf extract, it was found that the granules of bintaro leaf extract contained some secondary metabolite compounds namely alkaloids, flavonoids, saponins, and tannins. Tomlins (1986) alkaloids in bintaro leaves are repellent and antifeedant. [16] reported that polar active compounds in bintaro leaf extracts include flavonoids, saponins, and alkaloids.

Alkaloids are toxic substances to larvae that can cause death of test larvae. Alkaloids are salt so they can degrade cell membranes to enter and damage cells [16]. In the digestive tract, alkaloids can cause irritation by damaging the peritrophic membranes of the larval gastrointestinal tract [17].

How alkaloid works are to act as a stomach toxin. When the compound enters the body of the larvae its digestive device becomes disrupted [18]. Kale leaves (Ipomoea aquatica Forssk.) used as armyworms feed (Spodoptera litura Fab.) Firstly, it was sprayed with granule of bintaro leaf extract. Through the digestive tract of food or stomach, abdominal venom gets into the body of the Grayak caterpillar (S. litura Fab.). The toxin enters the larvae through the mouth of the larvae (through the food eaten) which then proceeds to the oesophagus, stomach, intestine, and anus.

Saponin is one of the most toxic compounds to insects [10]. Saponins have properties such as detergents that are considered being capable of increasing penetration of toxic substances because it can dissolve lipophilic material. How saponin works are to act as a contact toxic that affects the nervous system. Contact toxic enters the body of the Spodoptera litura Fab. larvae through the cuticle or directly related to bintaro seed extract. Toxic compounds that enter the body of the larvae interfere with the nervous system by inhibiting the action of acetylcholinesterase enzyme [16]. The acetylcholinesterase enzyme serves to solve acetylcholine into choline, acetic acid, and 
water [12]. When acetylcholine is accumulated, subsequent impulse delivery can not be transmitted to the brain and the larvae experience seizures continuously until paralysis and even death.

Tanin is a polyphenol compound that can form complex compounds with proteins. How tannins work is as a stomach toxic. Tannins cannot be digested and have a binding capacity of proteins, carbohydrates, vitamins and minerals [19]. Tannins can bind to lipids and proteins and can bind to protease enzymes that play a role in catalyzing proteins into amino acids which is necessary for the growth of larvae. Binding to the enzyme by tannin, then it causes the work of the enzyme to be inhibited so that the cell metabolism process can be disturbed and the larvae will be lack of nutrients. As a result, the growth of the larvae becomes obstructed and if this process continues, it will have an impact on larval mortality [20].

Cerberin is a class of alkaloids/glycosides (polar compounds) that are thought to contribute to insect mortality. Cerberin has toxic properties because it can interfere with calcium ion channels in the heart muscle of the larvae [6].

The development of armyworms larvae is strongly influenced by several factors, namely internal factors and external factors. Internal factors are factors affecting the development of larvae originating from the body of the larvae, while external factors are factors that affect the development of larvae derived from the surrounding environment.

The internal factors which are capable of causing death in test insects in this study are armyworms larvae, such as, morphological, physiological and biochemical properties. These morphological and physiological traits include the thickness of the cuticle and the differences in the insecticides in the insect body. While the biochemical properties of insects which are capable of causing death such as the presence of enzymes are capable of inactivating active substances in the insect body.
Meanwhile, the external factors that can affect the number of armyworms larvae mortality in the study are environmental factors that include temperature and humidity. In this study, the temperature and humidity of the room used for the study are not controlled but only measured to know if there is a change in temperature and humidity at the time of the research.

Based on the result of temperature and humidity measurement that has been done, it was found that the room temperature used in the research is the average of $31^{\circ} \mathrm{C}$, while the result of air humidity measurement on average is equal to $68 \%$. This is in accordance with the statement [21] which states that the optimum temperature for insects such as armyworms is between $29,4-32^{\circ} \mathrm{C}$ and humidity $(\mathrm{RH})$ of 60 $75 \%$ [22]. While the maximum temperature for insects according to [23] ranges from $40-45^{\circ} \mathrm{C}$.

\section{CONCLUSION}

Based on the result of granular toxicity study of Bintaro leaf extract (Cerbera odollam Gaertn.) on armyworms (Spodoptera litura Fab.), it is said that granula of Bintaro leaf extract (Cerbera odollam Gaertn). can cause death to the armyworms (Spodoptera litura Fab.) in the concentration range of $1.5 \%$. The $\mathrm{LC}_{50}$ value is $1.41 \%$. The higher the granular concentration of Bintaro leaf extract (Cerbera odollam Gaertn.), the higher the mortality of armyworms will be (Spodoptera litura Fab.).

\section{REFERENCES}

[1] Atmadja, W. R. 2011. Pemanfaatan Lima Jenis Insektisida Nabati untuk Mengendalikan Ulat Grayak (Spodoptera litura) pada Tanaman Cabe. Semnas Pestisida nababati IV, 163-176.

[2] Tarigan, Rustel., M. U. Tarigan, dan S. Oemry. 2013. Uji Efektifitas Larutan Kulit Jeruk Manis dan Larutan 
Daun Nimba untuk Mengendalikan Spodoptera litura F. (Lepidoptera: Noctuidae) Pada Tanaman Sawi di Lapangan. Jurnal Online Agroekoteknologi, 1 (1): 172-182.

[3] Kemtan (Kementerian Pertanian). 2009. Rancangan Rencana Strategis Kementerian Pertanian Tahun 20102014. Kementerian Pertanian, Jakarta. $184 \mathrm{hlm}$.

[4] Kartasapoetra, A.G. 1993. Hama Tanaman Pangan dan Perkebunan. Jakarta: Bumi Aksara.

[5] Djojosumarto, P. 2008. Pestisida dan Aplikasinya. Jakarta: Agromedia Pustaka.

[6] Tomlins, Russel S. 1986. Basic Word Order: Functional Principles. New South Wales: Room Helm Ltd.

[7] Tarmadi, D., AH. Prianto, I. Guswenrivo, T. Kartika, S. Yusuf. 2007. Pengaruh Ekstrak Bintaro (Cerbera odollam Gaertn.) dan Kecubung (Brugmansia candida Pers) terhadap Rayap Tanah Captotermes sp. J. Trop. Wood Scie.\& Tech. 5 (1).

[8] Maharani, S. 2016. Uji Toksisitas Fraksi Metanol dan N-Heksan Ekstrak Daun Bintaro (Cerbera Odollam G.) terhadap Mortalitas Ulat Grayak (Spodotera litura F.) dan Pemanfaatannya sebagai Buku Ilmiah Populer. Skripsi. Jember: Universitas Jember.

[9] Sa'diyah, N. A., Kristanti, I. P., Lucky, W. 2013. Pengaruh Ekstrak Daun Bintaro (Cerbera odollam) terhadap Perkembangan Ulat Grayak (Spodoptera litura F.). Jurnal
Sains dan Seni Pomits, 2 (2): 111 115.

[10] Utami, S. 2010. Aktivitas Insektisida Bintaro (Cerbera odollam Gaertn) Terhadap Hama Eurema spp. pada Skala Laboratorium. Jurnal Penelitian Hutan Tanaman 7 (4): 211-220.

[11] Finney, D. J. 1971. Probit Analysis, $3 r d$ ed. London : Cambridge University Press.

[12] Rizal, S. \& Hanjani, S. 2014. Pengaruh Serbuk Daun Rimau (Toona sinensis Roem.) terhadap Kematian Larva Ulat Grayak (Spodoptera litura F.). Sainmatika, 11 (1).

[13] Yudha, H.W. 2013. Efektivitas Ekstrak Buah Bintaro (Cerbera odollam) sebagai Larvasida Lalat Rumah (Musca domestica). Skripsi. Bogor: Institut Pertanian Bogor.

[14] Atmoko, T. dan A. Ma'ruf. 2009. Uji Toksisitas dan Skrining Fitokimia Ekstrak Tumbuhan Sumber pakan Orangutan terhadap Larva Artemia salina L. Jurnal Penelitian Hutan dan Konservasi Alam. 4 (1): 37-45.

[15] Sembel, D. 2015. Toksikologi Lingkungan. Yogyakarta: Andi.

[16] Cania, E. \& Setyaningrum, E. 2013. Uji Efektivitas Larvasida Ekstrak Daun Legundi (Vitex trifolia) terhadap Larva Aedes aegypti. Medical Journal of Lampung University, 2 (4).

[17] Ambarningrum, T. B., Pratiknyo, H. dan Priyanto S. 2009. Indeks Nutrisi dan Kesintasan Larva Spodoptera litura F. yang diberi 
Pakan Mengandung Ekstrak Kulit Jengkol (Pithecellobium lobatum Benth.). J. HPT Tropika. 9 (2): 109-114.

[18] Sari, R., Mifbakhuddin, dan Kiky Y. 2010. Pengaruh Konsentrasi Ekstrak Daun Tembelakan (Latana camara) terhadap Kematian Larva Aedes aegypti. Jurnal Kesehatan Masyarakat Indonesia. $6(2)$.

[19] Muta'ali, R., \& Indah K. 2015. Pengaruh Ekstrak Daun Beluntas (Pluchea indica) terhadap Mortalitas dan Perkembangan Larva Spodoptera litura F. Jurnal Sains dan Seni ITS, 4 (2) 2337-3520.

[20] Wahyuni, D., \& Loren I. 2015. Perbedaan Toksisitas Ekstrak Daun Sirih (Piper betle L.) dengan Ekstrak Biji Srikaya (Annona squamosa L.) terhadap Larva Nyamuk Aedes aegypti L. Saintifika, 17 (1) : 38-48.

[21] Palumbo, John C. 2011. Weather and Insects. UA Veg IPM Update, 2 (6)

[22] Qiqi, Yuan Jing, Yinzhao, Liming and Qingchun. 2012. Effects of Sublethal Concentration of The Chitin Synthesis Inhibitor, Hexaflumuron, on The Development and Hemolhymph Physiology of The Cutworm, Spodoptera litura. Jurnal of Insect Sciences, 2 (3): 16-23

[23] Neven, L. G. 2000. Physiological Responses of Insects To Heat. Postharvest Biology and Technology 21: 103-11. 